Article

\title{
Stagnating Jatropha Biofuel Development in Southwest China: An Institutional Approach
}

\author{
Jia Li ${ }^{1, *}$, Bettina Bluemling ${ }^{1}$, Arthur P. J. Mol ${ }^{1}$ and Thomas Herzfeld ${ }^{2,3}$ \\ 1 Environmental Policy Group, Wageningen University, Wageningen 6706 KN, The Netherlands; \\ E-Mails: Bettina.Bluemling@wur.nl (B.B.); Arthur.Mol@wur.nl (A.P.J.M.) \\ 2 Agricultural Economics and Rural Policy Group, Wageningen University, \\ Wageningen 6706 KN, The Netherlands; E-Mail: Herzfeld@iamo.de \\ 3 Leibniz Institute of Agricultural Development in Transition Economies (IAMO), \\ Halle 06126, Germany
}

* Author to whom correspondence should be addressed; E-Mail: lijiashy@hotmail.com; Tel.: +86-25-8454-1791.

Received: 22 November 2013; in revised form: 25 February 2014 / Accepted: 13 May 2014 / Published: 26 May 2014

\begin{abstract}
Biodiesel from jatropha has been considered as a promising alternative to fossil fuels for some time. Consequently, China started promoting jatropha as one of the options to meet its ever-increasing energy consumption, and the Chinese biodiesel industry also gained interest. However, the excitement of the biofuel industry in jatropha faded after it did not bring about the expected results. This article investigates the stagnation in jatropha development and production for biodiesel in China, using two detailed case studies of jatropha biofuel production in southeast China. It is found that the underdeveloped biodiesel policy and regulation, such as a rather late formulation of standards for biodiesel (especially the B5) and the absence of mandatory targets, is an important reason for hampering jatropha development. Besides that, lack of financial support undermined sustained jatropha planting at the farm level and lack of sustained commitment from state-owned enterprises or private companies over a long time span further contributed to jatropha project's failure. Better implementation of the rule of law, mandatory blending requirements, hazard insurance, as well as continuous financial support, might improve the continuation of jatropha plantation schemes.
\end{abstract}

Keywords: oil companies; smallholders; discourses; biodiesel; Sichuan; Guangxi 


\section{Introduction}

Global warming, high fossil fuel prices, an increasing alertness for energy security and greater recognition of the environmental consequences of fossil fuels create an urgent need to enlarge the development of renewable energy sources [1,2]. At the same time, liquid biofuels, as one of these renewable energy sources, have attracted criticism, among others regarding their competition with food crops for arable land. Policies to promote liquid biofuels have mushroomed worldwide over the past decade [3-6]. Like most countries, China has also shown an interest in promoting liquid biofuels as one option to diversify energy sources, in order to meet its ever-increasing energy consumption and prevent environmental problems related to fossil fuel-based energy use. Owing to China's limited per capita farmland and in the face of potential food security risks and global food price spikes in 2006-2007, the Chinese government has prohibited the production of biofuels from grain (i.e., corn, rice, wheat) and other major food crops. In this situation, biofuel production from oil trees on marginal lands appears as a promising alternative [7]. In particular, jatropha (Jatropha curcas L.) is considered a promising crop for generating raw material for biodiesel production. The Chinese government has consequently started to promote jatropha, with the Chinese biodiesel industry also starting to show an interest.

Jatropha trees produce seeds rich in oil that can be easily converted into biodiesel [8]. The processing of the seeds involves low technology and low cost equipment [9]. Ideally, plants should be exposed to between 900 and $1200 \mathrm{~mm}$ of rainfall per year [10]. They cannot stand frost. Trees are said to be vigorous, drought resistant and pest-resistant, as well as being able to grow on marginal land [10], which makes them less contested than other energy crops that compete for land, water and nutrients. However, jatropha cultivation is labour intensive. Finally, jatropha trees reach full production potential in the fifth year and produce seeds for up to 50 years [11].

Globally, jatropha trees are planted as both community and large-scale plantations. While community plantations have shown signs of success, the "road to large-scale biofuel production for developing countries is bumpy" [12]. Moreover, the largest share of investment in biofuel production goes into the establishment of large-scale plantations [12]. However, in smallholder contexts of developing countries, the implementation of large-scale plantations involves a considerable number of stakeholders who need to cooperate for a lengthy duration of time, i.e., from plantation to seed harvesting. Such failures of large-scale jatropha projects prompted Kant and $\mathrm{Wu}$ [13] to coin the current developments as the "collapse of jatropha as a global biofuel". In China, on the peak of the jatropha biofuel excitement in 2006, a considerable number of investment projects for the production of jatropha were announced by government and state-owned companies. However, since 2008, the great jatropha passion cooled down and no significant advances in jatropha biodiesel industry have been reported since then. Few studies have looked at the general causes of this failing jatropha biodiesel development, and remained focused on the technology dimension.

Against this background, this article analyses jatropha developments in China in general and explores the large-scale planting of jatropha as energy crop for biodiesel production. The study entails an analysis of jatropha policy development in China and of two detailed case studies of jatropha biofuel production in southeast China. Our central research question is: what are the main institutional reasons behind the stagnation of jatropha plantation. More specifically, we concentrate on the different 
time perspectives of the actors involved and their related behaviour. In this context, "time perspectives" are "composite cognitive structures that characterize the way an individual project, collects, accesses, values, and organizes events that reside in distinct temporal loci" [14]. However, to the best of our knowledge, very few studies have considered to what extent and how each of these institutional arrangements can help to overcome the differences in time perspectives that we have depicted above. The remainder of the paper is organised as follows. Section 2 provides an overview of Chinese policies to promote jatropha and jatropha biodiesel development status. Section 3 discusses the research methodology and analytical framework. Section 4 reports on the detailed case studies in Sichuan and Guangxi provinces. Section 5 discusses our findings and draws conclusions.

\section{Jatropha Biofuel Development in China}

\subsection{China's Jatropha Biofuel Policy}

As biofuels are new energy sources with currently higher production costs than fossil fuels, most governments have heavily supported and subsidised initial liquid biofuel developments [3]. Indeed, China has been no exception to this rule, where the cultivation of jatropha has been initiated and organised by the central government, while the implementation of specific jatropha projects falls under the responsibility of village committees and farmers. The national government has devised a series of laws and policies to support and promote jatropha plantations (see Table 1).

Table 1. National supportive policies for jatropha biofuels (2005-2011).

\begin{tabular}{|c|c|c|c|}
\hline Year & Name of law/policy & Publishing authority * & Most relevant content \\
\hline 2005 & $\begin{array}{l}\text { Renewable energy } \\
\text { industry development } \\
\text { supervision catalogue }\end{array}$ & NDRC & $\begin{array}{l}\text { Support of plantation and better variety } \\
\text { selection of energy crops including jatropha; } \\
\text { support of technological research, } \\
\text { demonstration projects, etc. }\end{array}$ \\
\hline 2006 & $\begin{array}{l}\text { National energy forest } \\
\text { construction plan }\end{array}$ & SFA & $\begin{array}{l}\text { Planting target for } 2020: 13 \text { million ha } \\
\text { energy forests including jatropha with supply } \\
\text { of raw material for } 6 \text { million ton biodiesel } \\
\text { and } 15 \text { million watt electricity. }\end{array}$ \\
\hline 2006 & $\begin{array}{l}\text { "The Eleventh Five-Year" } \\
\text { construction scheme } \\
\text { for oil-bearing energy } \\
\text { forest base }\end{array}$ & SFA & $\begin{array}{l}\text { Planting target of the eleventh five-year plan } \\
\text { (2006-2010): } 400,000 \text { ha jatropha in } \\
\text { Sichuan, Yunnan, Guizhou, and } 433,000 \text { ha } \\
\text { other oil-bearing forest. }\end{array}$ \\
\hline 2006 & $\begin{array}{l}\text { Interim instrument on } \\
\text { Renewable Energy } \\
\text { Development } \\
\text { Special Fund }\end{array}$ & $\mathrm{MOF}$ & $\begin{array}{l}\text { Special fund provided by central government } \\
\text { for, among others, biodiesel from seeds; } \\
\text { Regulation of procedures of application } \\
\text { and approval, financial management } \\
\text { and monitoring; } \\
\text { Subsidy standard of } 3000 \text { RMB per ha for } \\
\text { energy forest including jatropha (conditional } \\
\text { on contract with pilot company). }\end{array}$ \\
\hline
\end{tabular}


Table 1. Cont.

\begin{tabular}{|c|c|c|c|}
\hline Year & Name of law/policy & Publishing authority * & Most relevant content \\
\hline 2006 & $\begin{array}{l}\text { Implementation guideline } \\
\text { on financial and tax } \\
\text { support for renewable } \\
\text { energy and } \\
\text { biochemical industry }\end{array}$ & $\begin{array}{l}\text { MOF } \\
\text { NDRC } \\
\text { MOA } \\
\text { SAT } \\
\text { SFA }\end{array}$ & $\begin{array}{l}\text { Introduction of the "Not compete with grain" } \\
\text { principle and encouragement of the use of } \\
\text { marginal land; } \\
\text { Utilisation of jatropha seeds to produce } \\
\text { biofuels encouraged; } \\
\text { Financial support (deficiency payment } \\
\text { for enterprises processing jatropha seeds } \\
\text { conditional on crude oil price; subsidy } \\
\text { for energy forests and demonstration plots) } \\
\text { and tax preferences. }\end{array}$ \\
\hline 2007 & $\begin{array}{l}\text { Medium-long-term } \\
\text { development plan on } \\
\text { renewable energy }\end{array}$ & NDRC & $\begin{array}{l}\text { Biodiesel production from energy crops } \\
\text { as political goal; } \\
\text { Establishment of jatropha-breeding } \\
\text { biodiesel experimental projects in } \\
\text { Sichuan and other provinces; } \\
\text { Increase of annual target of biodiesel } \\
\text { use from 200,000 tons (2010) to } \\
2 \text { million tons (2020); } \\
\text { Blending targets with liquid biofuel } \\
\text { for petroleum and diesel. }\end{array}$ \\
\hline 2007 & $\begin{array}{l}\text { Management instruction } \\
\text { on financial subsidy } \\
\text { supporting the crops } \\
\text { which produce non-grain } \\
\text { renewable energy and } \\
\text { biochemical products }\end{array}$ & MOF & $\begin{array}{l}\text { Definition of conditions for financial support: } \\
\text { A refinery and capacity is required to be } \\
\text { qualified to receive the subsidy; } \\
\text { More than } 20 \text { thousand ha plantation and } \\
\text { more than } 33.3 \text { ha nursery field are required. }\end{array}$ \\
\hline 2007 & $\begin{array}{c}\text { Biodiesel Blend Stock } \\
\text { (BD100) for diesel } \\
\text { engine fuels }\end{array}$ & $\begin{array}{c}\text { GAQSIQ } \\
\text { SA }\end{array}$ & Setting a quality standard for biodiesel. \\
\hline 2011 & Biodiesel Fuel Blend (B5) & $\begin{array}{c}\text { GAQSIQ } \\
\text { SA }\end{array}$ & $\begin{array}{l}2 \%-5 \% \text { biodiesel blending with } \\
95 \%-98 \% \text { diesel. }\end{array}$ \\
\hline
\end{tabular}

* NDRC National Development and Reform Committee; MOF Ministry of Finance; MOA Ministry of Agriculture; SAT State Administration of Taxation; SFA State Forestry Administration; GAQSIQ General Administration of Quality Supervision, Inspection and Quarantine; $S A$ Standardisation Administration; Land area is given in $h a$, on the base of the original Chinese unit of $m u(15 m u=1 \mathrm{ha})$.

Table 1 shows that a national supportive policy to promote biofuels from jatropha has been developed in China, particularly from 2005 onwards. Different governmental agencies have set numerous measures to facilitate, stimulate and regulate renewable energy production from jatropha biofuels. Five governmental agencies have formulated guidelines for financial support and facilities to stimulate liquid biofuel production, namely the Ministry of Finance (MOF), Ministry of Agriculture (MOA), State Administration of Taxation (SAT), National Development and Reform Committee (NDRC), and State Forestry Administration (SFA). However, these guidelines have not necessarily contributed to stable long-term favourable perspectives for jatropha plantations. For instance, SAT's tax exemption 
for biodiesel, published in 2005, was already abolished in 2008. In 2007, standards were published for biodiesel production. The Biodiesel Blend Stock (BD100, 100\% biodiesel) for Diesel Engine Fuels was published in 2007, and the biodiesel fuel blend (B5, 5\% biodiesel) was published in 2011. In contrast to many developed countries, which have created a liquid biofuel market by setting compulsory targets for blending, China has no mandatory blending target for biodiesel. Hence, the development of a biodiesel industry that is embedded in a robust market environment remains in its infancy [11].

\subsection{Jatropha Biofuel Projects in China}

Apart from creating a national niche market for jatropha biodiesel, clearly outlined programmes and plans can support a convergence of different time perspectives. In The Eleventh Five-Year construction scheme for oil-breeding energy forest bases, published by the SFA in 2006, a Forestry-Oil Integration (linyou yitihua) Scheme was formulated in which jatropha plantations were to be increased in three provinces: Sichuan, Guizhou and Yunnan [15]. In this plan, an institutional arrangement was set up between state-owned oil companies and SFA to promote energy forest plantations and biofuel production. CNPC, China's largest state-owned oil company, first entered in a collaborative relation with SFA, with two other major state-owned oil companies, SINOPEC (China Petroleum \& Chemical Corporation) and CNOOC (China National Offshore Oil Corporation), later joining this cooperation. Following these state-owned companies and further attracted by governmental promotional policies, private companies have also become involved in jatropha plantation.

In China, provinces often complement such national programmes and plans with regulations and policies. Sichuan and Guizhou provinces included jatropha promotion in their province-specific Eleventh Five-Year Development plan [16,17], aiming for around 600,000 and 400,000 hectares planted with jatropha in 2020, respectively [7,15]. Biodiesel industry development from jatropha was also written into the No 1 document of Guizhou People's Government in 2007 [15]. Moreover, besides these three provinces, other south-western provinces have also developed policies to stimulate jatropha plantation, as well as downstream biodiesel production and use. Therefore, CNPC, SINOPEC, CNOOC and other private companies and governmental agencies have built or planned to build many jatropha feedstock based projects (see Table 2).

However, many of the planned projects in Table 2 have not been implemented or were discontinued. At the end of 2006, the US Company Beck Ltd withdrew from China, after having invested 2.6 million RMB in jatropha plantations. Moreover, the UK Company Sun biofuel left Sichuan because the company could not agree with the Panzhihua city government, Sichuan Province, about how much it had to invest to continue jatropha production [18]. Various other jatropha projects of CNPC, SINOPEC and CNOOC have discontinued and CNPC and CNOOC have stopped investing money in jatropha projects [19]. The NDRC project ( $c f$. Table 2) in Guizhou province also did not continue after 2008 (interview with scientists and government officers). Moreover, according to Hainan Daily [20], the area of jatropha planted decreased between 2009 and 2011 as several private companies withdrew. 
Table 2. Planned and realized jatropha plantation projects and investments in China from 2006-2008 (own survey, [21]).

\begin{tabular}{|c|c|c|c|}
\hline Project name & Investment scale & Project site & Investment (RMB) \\
\hline $\begin{array}{l}\text { CNPC Jatropha feedstock base } \\
\text { with Panzhihua Government }\end{array}$ & $20.0 \times 10^{4}$ ha & $\begin{array}{l}\text { Panzhihua City, } \\
\text { Sichuan }\end{array}$ & 2.3 billion \\
\hline $\begin{array}{l}\text { American Baker biofuel company } \\
\text { with Panzhihua Government }\end{array}$ & $20.0 \times 10^{4}$ ha & Panzhihua & 9.6-12 billion \\
\hline Sunshine technology group UK & $6.7 \times 10^{4}$ ha & Panzhihua & 4 billion \\
\hline $\begin{array}{l}\text { SINOPEC, Panzhihua energy } \\
\text { forest base and biodiesel refinery }\end{array}$ & $3.0-3.5 \times 10^{4} \mathrm{ha}$ & $\begin{array}{l}\text { Panzhihua City, } \\
\text { Sichuan } \\
\end{array}$ & Unknown \\
\hline $\begin{array}{l}\text { CNOOC, Panxi Jatropha } \\
\text { biodiesel industry base }\end{array}$ & $15.0 \times 10^{4} \mathrm{ha}$ & $\begin{array}{l}\text { Panzhihua City, } \\
\text { Sichuan } \\
\end{array}$ & 2.347 billion \\
\hline CNOOC & $6 \times 10^{4}$ ton biodiesel & Dongfang, Hainan & Unknown \\
\hline $\begin{array}{l}\text { Hainan CNOOC, New Energy } \\
\text { Industrial Co., Ltd }\end{array}$ & 1500 ha & Hainan & Unknown \\
\hline $\begin{array}{l}\text { Hainan Honglv Zhengke } \\
\text { bioenergy development Co. }\end{array}$ & $8.5 \times 10^{4}$ ha & Hainan & 53 million \\
\hline $\begin{array}{l}\text { CNPC jatropha feedstock } \\
\text { base with State Forestry } \\
\text { Administration } \\
\text { (Lincang city, Yunnan province ) }\end{array}$ & $1 \times 10^{4}$ ha & $\begin{array}{l}\text { Lincang city, } \\
\text { Yunnan }\end{array}$ & Unknown \\
\hline Sunshine Technology Group, UK & $2.0 \times 10^{4}$ ha & $\begin{array}{l}\text { Red River Basin } \\
\text { in Yunnan }\end{array}$ & Unknown \\
\hline $\begin{array}{l}\text { Yunnan Shenyu } \\
\text { new energy group }\end{array}$ & $2.0 \times 10^{4} \mathrm{ha}$ & Chuxiong, Yunnan & 0.8 billion \\
\hline $\begin{array}{l}\text { National Development and } \\
\text { Reform Commission, } \\
\text { standardized planting } \\
\text { of jatropha and commercial } \\
\text { demonstration base }\end{array}$ & $4.0 \times 10^{4}$ ha & Guizhou & Unknown \\
\hline Liuzhou Minghui Biofuels Co. & $30 \times 10^{4}$ ton biodiesel & Liuzhou, Guangxi & Unknown \\
\hline $\begin{array}{l}\text { Guangxi Zhilian Renewable } \\
\text { Energy Company }\end{array}$ & $3 \times 10^{4}$ ha & Pingguo, Guangxi & Unknown \\
\hline
\end{tabular}

In 2006, the National Development and Reform Commission approved the first three domestic Jatropha biodiesel processing demonstration projects: CNPC Nanchong Refinery (60,000 ton/year), SINOPEC Guizhou branch (50,000 ton/year) and CNOOC Hainan (60,000 ton/year). Until now, only CNOOC Hainan processing project has been built. However, because the jatropha feedstock base has not been planted, at present it produced biodiesel mainly from sulphated oil. More than 100 biodiesel enterprises are mainly dependent on waste cooking oils and animal fats as feedstock [22]. This is also confirmed by the distribution and planted area of jatropha (Table 3).

The establishment of jatropha plantations started in 2006 on a massive scale mainly in southwest China, including the provinces Yunnan, Sichuan, Guizhou, Guangxi and Hainan [11,21,22]. Most recently, the jatropha area (including natural forests) covers 200,000 ha. Table 3 presents the distribution of areas across the five provinces. 
Table 3. Area with jatropha in China (data from [21]).

\begin{tabular}{cccc}
\hline Province & Natural area $\left(\times \mathbf{1 0}^{\mathbf{3}} \mathbf{h a}\right)$ & Planted area $\left(\times \mathbf{1 0}^{\mathbf{3}} \mathbf{h a}\right)$ & Planned area $\left(\times \mathbf{1 0}^{\mathbf{3}} \mathbf{h a}\right)$ \\
\hline Yunnan & 33.3 & 83.3 & 666.7 \\
Sichuan & 10.3 & 33.3 & 666.7 \\
Guizhou & - & 15 & 40 \\
Hainan & - & 6.7 & 200 \\
Guangxi & - & 15 & - \\
\hline
\end{tabular}

In conclusion, until 2013 the production of biodiesel from jatropha remained at the very early stage, with current annual yields of biodiesel from crude jatropha oil at less than 100 tonnes [21,22]. Inadequate jatropha feedstock supply is considered a major obstacle to jatropha biofuel development in China (see Table 3). In understanding why the area of planted jatropha and the supply of feedstock to the biodiesel plants are not expanding, in what follows, two cases of large-scale jatropha projects are analysed.

\section{Methodology: Case Study and Analytical Framework}

\subsection{Case Study}

Case studies are employed to analyse large-scale jatropha projects in China. Case studies prove especially valuable when investigating a contemporary complex phenomenon within its real-life context, where boundaries between phenomenon and context are not clearly evident, and "how" and "why" questions are being asked [23,24].

Given that case study methodology has limitations in terms of the generalisation of results and external validity, the selection of case studies is crucial. In this respect, a two-step selection process was undertaken. First, two out of the five Chinese provinces that have favourable conditions for jatropha growth and have installed policies to stimulate jatropha plantations were selected. Accordingly, Sichuan and Guangxi were chosen, as both provinces are located in southern China and have suitable subtropical climatic conditions to grow jatropha. In economic terms, both provinces represent provinces with a below average wealth in terms of per capital GDP. This holds for the provincial level as well as for rural areas. Sichuan has the second largest area of established jatropha plantations in China [22]. Guangxi also has established a fair number of jatropha plantations, but does not belong to the initial three provinces of the Forestry-Oil Integration Scheme.

Second, based on the overview of the jatropha biodiesel projects, two different institutional arrangements to establish plantations have been identified thus far. Whereas market driven arrangements - whereby farm households cooperate and contract with private companies - appear the standard in Western contexts, government driven arrangements with a high involvement of local and higher level government offices and state-owned enterprises remain fairly common in China today. An example of a government driven jatropha plantation arrangement was selected in Sichuan. From 2006, mainly government driven projects developed in Sichuan. The government driven project we selected is the first project in the Forestry-Oil Integration Scheme, in which the state-owned CNPC cooperated with SFA on jatropha. Guangxi has no jatropha projects involving state-owned companies with a government driven institutional arrangement. In Guangxi, jatropha plantations are predominantly 
initiated by private companies and hence are typically market driven institutional arrangements. Hence, a case of a market driven institutional arrangement project was selected in Guangxi. As such, the two cases are representative for the two institutional arrangements and substantially differ in terms of how actor configurations and policies approach the development of jatropha plantation and related to liquid biofuels production.

In each of the two provinces, provincial level representatives of the SFA provided an overview of the large-scale jatropha plantation projects that have been initiated in recent years. From their list, one project in each of the provinces was selected, based on the criteria of accessibility, available information on project implementation and minimum cultivation scale. The fieldwork on the two cases was carried out in 2010, using in-depth semi-structured interviews with key stakeholders and document analysis as the main research methods. Key stakeholders included decision makers from four administrative levels, as well as the village committee, scientists and company officials. More specifically, interviews were held with officers of the State Forestry Administration in charge of energy crops, including jatropha, provincial forestry department officers in charge of jatropha projects, county forestry department officers in charge of the jatropha plantation, township forestry officers where jatropha was planted, as well as village leaders of villages taking part in the jatropha plantation. Moreover, interviews were also conducted with three scientists, one previous staff member of the private company, two staff members from the state-owned company, as well as three NGO spokespersons. The semi-structured interview was designed by mapping out the relevant actors, resources, rules of the game and discourse characteristics around the two jatropha projects [25].

\subsection{Analytical Framework}

Policies and targets as described above need to be implemented by stakeholders on the ground. The concepts of institutional arrangements can be applied to analyse such implementation processes. Here, "institutional arrangements" are employed in a similar way as Arts et al. [25] using policy arrangements, i.e., a temporary stabilised actor network with resource dependencies among the actors and specific rules of the game. As briefly mentioned above, we identified two types of jatropha institutional arrangements in China: government driven and market driven. The term government driven arrangement refers to jatropha plantation projects that are initiated by governmental stakeholders, implemented by governmental and/or other stakeholders and in which governmental rules play a significant role. The term market driven institutional arrangements refers to plantations that are initiated and implemented by market actors such as companies and smallholders, to a major extent according to market rules.

In order to facilitate the development of a project, an institutional arrangement aims at reducing uncertainty about future outcomes via three different ways. First, we assume that uncertainty is reduced when each actor contributes with resources to the arrangement and rules prevent the withdrawal of different stakeholders. Resources can be land, property, seedlings, financial credit/support, staff support, knowledge, access to certain actor groups, means of communication, legal power, committee membership, and access to market channels [26,27]. Contribution to the jatropha project/arrangement with any of these resources shows commitment, but includes vulnerability in case the project/agreement fails. Actors are vulnerable to other actors withdrawing their resources, which is referred to as "mutual resource dependency" [28]. Furthermore, the contribution of resources over time 
is crucial. It is assumed that future outcomes for actors will be clearer where actors are involved over several time steps, bridging to future outcomes.

Second, the rules of the game, including sanctioning mechanisms, help to prevent stakeholders from withdrawing from the agreement and secure the protection of vulnerable stakeholders. We follow Arts et al. [25] in defining rules of the game as the unwritten constitution of the arrangement that guides the behaviour and interaction of actors and influence the strategic deployment of their resources. The presence of sanctioning mechanisms is assumed reduce uncertainty as these incentivize towards rule conform behaviour.

Third, the uncertainty of future outcomes is reduced when actors share a discourse around the arrangement. The concept of discourse refers to "the views and narratives of the actors involved" [25]. Here, a discourse is understood as "a dominant interpretative scheme" by which meaning is given to the respective joint initiative [28]. Given the long duration of the jatropha institutional arrangements, "discourse" obtains the notion of a "vision", which can have the potential to mobilise stakeholders [29]. However, a discourse can also imply persuasion, employing the "power of arguments" and defining what is legitimate behaviour [28]. Hence, the convergence of different discourses around the arrangement would keep the persistence of the institutional arrangement over time by reducing uncertainty. However, if the discourse is divergent, then uncertainty might increase. Long-time horizons are known to fail in evoking commitments [30], given that they involve a "range of uncontrollable and unpredictable factors operating in the future" [31]. Under such conditions, institutional arrangements are crafted to create time perspectives that bring added value to today's risk-taking decisions [32].

Long-term profitability and short-term liquidity are important characteristics in a plantation's planning [33]. Delay in investment return is a crucial aspect for planters with liquidity constraints [34]. Some actors in jatropha institutional arrangements (farmers, local government staff) focus on annual income revenue to cover their costs, especially when their yearly expenses are relatively high. For other actors (companies and central government), biofuel production from jatropha might only form a minor share of their total activities and budgets. Therefore, for them, the future income or general profitability of the project is more important in determining success. These diverging (time) perspectives in jatropha investments are to some extent comparable to other sectors; for instance, investment in forestry or orchards needs to deal with a long time horizon before returns capitalise, which is problematic for small forestry farmers $[30,35]$.

\section{Analysis of Two Institutional Arrangements}

This section introduces and analyses the two jatropha projects-government driven and market driven institutional arrangements. Each case will be described by starting with the respective arrangement and its implementation, focusing on actors' contributions, resource dependencies and the arrangement's embedding in a discourse. Subsequently, the performance of each institutional arrangement will be presented in terms of the de facto planted area and realised biodiesel production. Finally, several lessons will be reflected from each case study. 


\subsection{Government Driven Arrangement: Sichuan Province}

\subsubsection{Institutional Arrangement}

Within the Forestry-Oil-Integration Scheme, the long-term target for new jatropha plantations in Sichuan province is 600,000 ha by 2020 , while the five-year target from 2007 onwards is 200,000 ha (interview Sichuan Forestry Administration). To achieve these targets, the Sichuan provincial government has set up an arrangement in which the company CNPC plays a pivotal role. CNPC is a financially independent state-owned company, developed out of the Ministry of Oil Industry in 1988 as part of China's development towards a market economy. However, CNPC still has close ties with the government, given that its leaders are appointed by the Chinese Communist Party. CNPC is considered as a ministry level state-owned company (hence, its highest leader is equal to a minister). The cooperation between CNPC and SFA as well as the Sichuan provincial government can be considered as a horizontal cooperation between different government sectors (see Arrow 1 in Figure 1).

Figure 1. Jatropha project governance structure in Sichuan province.

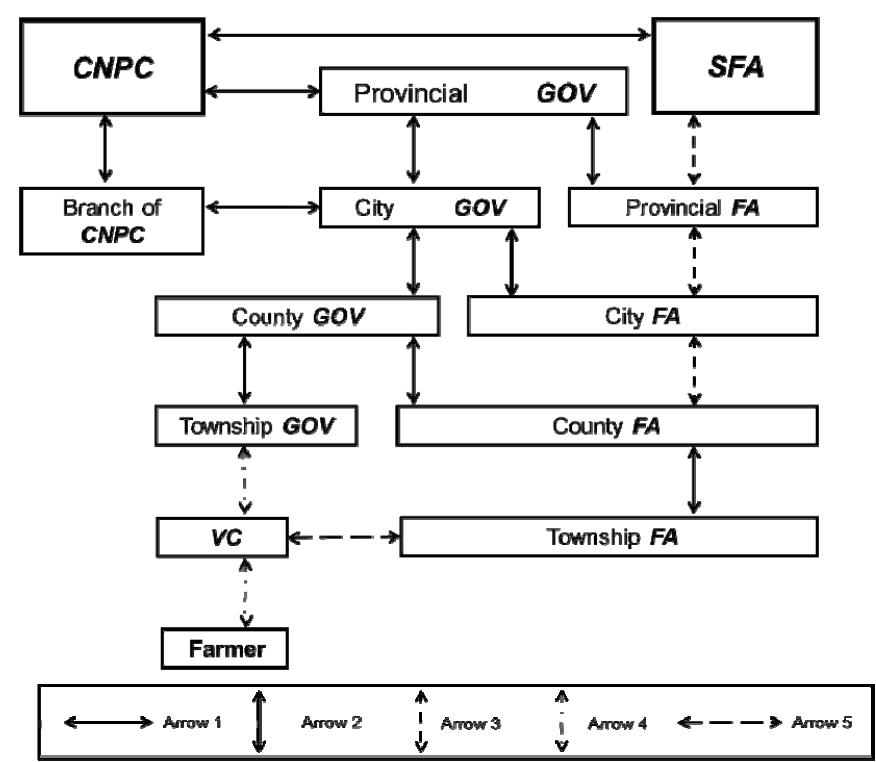

Arrow1 Horizontal Cooperation, Arrow 2 Administration Jurisdiction (appointment and financial resources decided by higher level), Arrow 3 Supervision (the lower level implements policy from higher level and is under higher level supervision), Arrow 4 Governing by Provision (the higher level governs the lower level by resource provision) (Kern and Alber, 2009) Arrow 5 cooperation based on agreement (the actors work together according to oral agreement or written contract). $V C$ Village Committee, GOV Government, FA Forest Administration.

These two parties signed an agreement on jatropha projects in 2006, according to which, both parties will work together to realise a "100,000 ton scale" jatropha based biodiesel pilot plant. The provincial Forestry Administration conducted an inventory of marginal land suitable to grow jatropha and the original distribution of wild jatropha, presenting the survey results to CNPC. Based on the results and a field trip, the provincial Forestry Administration and CNPC selected project plots and set a planting target for a five-year period. They agreed upon the realisation of jatropha plantations in Panzhihua City and Liangshan Minority Autonomous City. For these levels, the cooperation between 
the branch of CNPC in charge of these projects and the two city governments can also be considered as a horizontal cooperation (see Arrow 1 in Figure 1). CNPC signed an agreement with Liangshan city government to plant an area of 120,000 ha jatropha demonstration plots, as well as with Panzhihua city government to plant an area of 80,000 ha jatropha demonstration plots. The realisation of this long-term goal was to be achieved in several steps. In 2007, Panzhihua and Liangshan governments were obliged to plant together 13,330 ha with jatropha and 16,670 ha in 2008 . However, the new plantation did not continue after 2008 (interview Sichuan Forestry Administration officer).

In these agreements, Liangshan and Panzhihua city governments would ensure forestland availability, promise to coordinate the implementation of plantations, i.e., to arrange labour and provide planting supervision, as well as organising the harvest, the collection of the seeds and transporting them to CNPC. Township Forestry Administrations would support the collection of seeds by farmers, while CNPC would pay a small fee to the Township Forestry Administration for this service. CNPC ensured providing subsidies for the plantation, as well as promising to purchase all jatropha seeds and process them to biofuel. CNPC would buy these seeds at a market price if it exceeded the guaranteed price of $3 \mathrm{RMB} / \mathrm{kg}$. The collected seeds would be transported by the Township Forestry Administration to a simple extracting plant that produces the raw product, before being transported to a more centrally located refinery. Nanchong refinery of CNPC was a registered project at the NDRC, which consists of a 60,000 ton production line to extract the raw jatropha oil. The realisation of this agreement received support by the Ministry of Finance (MOF) and CNPC, who each would contribute $50 \%$ to the planned budget.

In conclusion, the institutional arrangement sets time-steps and concrete quantitative future outcomes. Furthermore, actors across the entire production chain are involved and contribute resources. We can assume that future outcomes of the agreement are rather certain. National government together with city and county/township governments contribute the most in terms of resources (see Table 4).

For the implementation, the planting task was distributed downwards via the county and township governments to the village committee. In the terminology of Kern and Alber [36], the relationship presents governing by provision as the higher level governs the lower level by resource provision (see Arrow 4 in Figure 1). The Forestry Administrations at each level are in charge of implementation. The subsidies of the MOF had to be distributed via the respective county administration to the participants. In the four counties, the county Forestry Administration and the township government employed their access to those realising the plantation, i.e., they persuaded large (institutional) forest landholders and village committees. In turn, the village committees persuaded the villagers to take part in jatropha plantation by supplying seedlings, fertilisers, paying wages and promising that CNPC would purchase the final product with the help of the Township Forestry Administration. The persuasion of farmers applied economic arguments of increasing the villagers' incomes. Costs for setting up jatropha plantations are covered by the subsidy of the MOF (3000 RMB/ha) and CNPC (3000 RMB/ha). During the implementation, subsidies only address expenses for the first year. 
Table 4. Contribution of resources to government driven arrangement.

\begin{tabular}{|c|c|c|c|}
\hline \multirow{2}{*}{ Actor } & \multicolumn{3}{|c|}{ Resources contributed to arrangement } \\
\hline & Category & Description & Time dimension \\
\hline MOF & Finance & $\begin{array}{l}50 \% \text { of cultivation investment } \\
\text { (seeds, labour) in planned budget }\end{array}$ & $\begin{array}{l}\text { The subsidy of } 2007 \\
\text { distributed after plantation } \\
\text { in } 2007 \text {; } \\
\text { The subsidy of } 2008 \\
\text { distributed in } 2010\end{array}$ \\
\hline \multirow[t]{3}{*}{$\begin{array}{l}\text { Liangshan/Panzhihua } \\
\text { governments }\end{array}$} & Staff & $\begin{array}{l}\text { Staff for the coordination of } \\
\text { jatropha plantation, seed harvest, } \\
\text { collection * and transport; } \\
\text { Technical service staff for jatropha } \\
\text { cultivation }\end{array}$ & $\begin{array}{l}\text { Plantation period and } \\
\text { harvest period }\end{array}$ \\
\hline & Infrastructure & Transportation & $\begin{array}{l}\text { Before and during } \\
\text { harvest period }\end{array}$ \\
\hline & Access & Access to forestland & $\begin{array}{l}\text { Before and during } \\
\text { plantation period }\end{array}$ \\
\hline $\begin{array}{l}\text { County Forestry } \\
\text { Administration/ } \\
\text { township } \\
\text { government }\end{array}$ & Access & $\begin{array}{l}\text { Access to farmers: use of } \\
\text { argumentative power for persuasion; } \\
\text { Access to higher level: use of } \\
\text { subsidies from MOF for persuasion; } \\
\text { Access to CNPC }\end{array}$ & $\begin{array}{l}\text { Before and during } \\
\text { plantation period; } \\
\text { Before and during } \\
\text { plantation period; } \\
\text { Before and during plantation } \\
\text { period, harvest period }\end{array}$ \\
\hline CNPC & Finance & $\begin{array}{l}50 \% \text { of cultivation investment } \\
\text { (seeds, labour) in planned budget; } \\
\text { Purchase of all jatropha seeds at } \\
3 \mathrm{RMB} / \mathrm{kg} \text { or higher (market price). }\end{array}$ & $\begin{array}{l}\text { The subsidy of } 2007 \\
\text { distributed after plantation } \\
\text { in } 2007 \text {; } \\
\text { The subsidy of } 2008 \\
\text { was not paid }\end{array}$ \\
\hline Villagers & Labour & & $\begin{array}{l}\text { Plantation period and } \\
\text { harvest period }\end{array}$ \\
\hline
\end{tabular}

* Against a small fee by CNPC.

\subsubsection{Performance}

The planted area in 2007 was 14,667 ha, i.e., more than the target for that year; in 2008, 15,333 ha were planted, which was a little less than the original target. Overall, the sum of the two years' plantations reached the annual targets. Out of the two sources of subsidies, MOF and CNPC, the MOF paid its subsidies to the provincial Department of Finance (DOF) after inspection. The money has been transferred to planters and employed farmers via the county Department of Finance and the Forestry Administrations. However, subsidies from CNPC for 2007 and 2008 did not arrive at the county level until 2010. For the start of the Forestry-Oil Integration Scheme, the county government and Forestry Administration paid this part of CNPC's investment from their own resources. Hence, smallholders who were involved in the jatropha plantation of 2007 received the subsidy on time. However, the MOF subsidy for new jatropha plantations in the second year, due in 2008, was only distributed to the county Forestry Administration in 2010. The reason for this delay lies in the requirements for receiving 
MOF subsidies, with the MOF stipulating that a jatropha plantation needs a contract with a pilot company, and that the enterprise needs to have a refinery in its vicinity. In the second year, CNPC withdrew from the project, with the construction of the Nanchong refinery also stopping after 2008, before it entered into the production stage (interview with Forestry Administration officer). This implied that farmers' jatropha plantations did not have access to a refinery, which led to the MOF stopping financial flows. However, after farmers lobbied at the local Forestry Administration, and the latter lobbied at higher level Forestry Administration departments, subsidies were finally transferred to farmers. The national government eventually paid the subsidy and farmer wages could be paid, albeit with considerable delay. After withdrawing from the arrangement, CNPC did not pay the second year subsidy. Consequently, the local government and farmers stopped planting and cultivating jatropha. A county report [37] showed that the county Forestry Administration had a large debt due to their spending on seedlings and fertilisers, causing an absence of payments to large forestry farmers and their employees. This created conflicts between employed farmers and the local government.

Due to low investments in intensive cultivation, the productivity and yield of jatropha is considerably lower than initially expected. Nowadays, jatropha plantations from the first and second year still exist. However, the average production each year is around $750 \mathrm{~kg} / \mathrm{ha}$, compared to the initially expected $4500 \mathrm{~kg} / \mathrm{ha}$.

\subsubsection{Lessons}

The Sichuan case is part of the Forestry-Oil Integration Scheme. The plan is embedded in the general governmental strategy on measures for combating global warming, building on forests' ecological functions and the contribution of renewable (energy) resources to sustainable development [38-40]. Hence, jatropha is promoted to combat global warming and increase renewable energy sources. Nonetheless, for Forestry Administrations at the provincial, county and township level, reporting on political achievements, such as plantation targets, is crucial. For the County Forestry Administration and the Township Forestry Administration, the present plantation and costs have priority over future seeds and biodiesel. For village leaders and villagers, present cash income is most important, to cover their daily life and consumption. As a result, the plantation discontinued as without the flow of subsidy current net costs for villagers, village leaders and the Township Forestry Administration were high; future gains had much less priority.

In the case in Sichuan, the local government and farmers seem to be in a situation of mutual resource dependency, according to which the government depends on farmers' willingness to contribute with labour, while the farmers depend on the government for access to programmes and monetary resources. Both parties lose future options of cooperation if they default on the arrangement. However, CNPC is not such a place-based actor and can seek future options in other places. Compared to the local government and farmers, CNPC is less resource dependent on the other actors and is more flexible to step out and move resources to other places and investments. Due to the absence of mutual resources dependency with CNPC, the uncertainty of future outcomes could not be reduced.

The rules of the game of government driven arrangements are characterised by the embeddedness in the present organisation of the Chinese economy, i.e., a sort of market orientation with strong government characteristics and top-down administrative planning and regulation. The withdrawal of CNPC from the plantation and the closure of their Nanchong refinery can be partly attributed to a 
leadership change in CNPC. While the former leader was enthusiastic about jatropha and showed commitment and vision, the new CNPC leader was hardly interested and terminated subsidies, a situation that is not uncommon in China [41]. Furthermore, the cooperation between the city government, the Forestry Administration and CNPC was based on a fairly general agreement, without any provisions concerning punishment in the case of non-compliance, as opposed to a standard contract with legal power. The agreement was quite vulnerable to external shocks.

In conclusion, farmers and the local government, who depend on subsidy, quit to grow jatropha when there was no financial support from the state-owned company and the national government. Lack of sustained commitment from the state-owned company resulted in failure of this government driven project. Farmers seem to be the weakest actor as they had no means to sanction noncompliant behaviour from the state-owned company. Although, the low productivity of jatropha may have played a role in project discontinuation, there is not sufficient production information to draw any lasting conclusions in this regard.

\subsection{Market Driven Arrangement: Guangxi Province}

\subsubsection{Institutional Arrangement}

In Guangxi, private companies rather than state-owned oil companies initiated jatropha plantations. Guangxi Zhilian Renewable Energy Company (GZREC) was the largest and most notable private energy company involved in jatropha-based biofuel production. GZREC was set up in 2007, cooperating with the International Jatropha Association, specialised in jatropha genetic research, seedling cultivation, jatropha forest development and biodiesel production (interview with Guangxi Forestry Administration officer). The company started plantation by using a contract farming scheme with the village committee.

The company started plantations in Pingguo County, due to its large area of marginal forestland and long history of jatropha. GZREC came into contact with the rather impoverished Burong administration village in Pingguo County through an introduction by the office of poverty alleviation. After initial contacts, the company negotiated directly with the village leader. The village leader subsequently investigated several jatropha biofuel companies in Nanning city (the capital of Guangxi province), checking information on the internet concerning the company and biofuel production. Only then did he decide to cooperate with GZREC. The private company decided on the planting area after discussing with the village committee. Hence, the two actors had a vision of feasible future outcomes in terms of the planted area. The company and Burong village committee signed a written contract; accordingly, the cooperation between the company and villagers can be seen as contract farming, which is a market arrangement (see Figure 2). This contract arranged that the village would supply land and coordinate labour, while the company would supply seedlings, fertilisers, compensate for labour costs and provide technical services. The company agreed to offer basic labour wages at around $30 \mathrm{RMB}$ per person per day. Moreover, the company also agreed to buy the seeds at a guaranteed price, and if the market price was higher than the guaranteed price, they would buy the seeds at the higher market price. For the realisation of the agreement, GZREC applied for a subsidy from the MOF (interview with village leader). This arrangement did not involve much risk for the farmers, while income generation was secured for the initial labour investment. 
Figure 2. Jatropha contract farming scheme in Guangxi province.

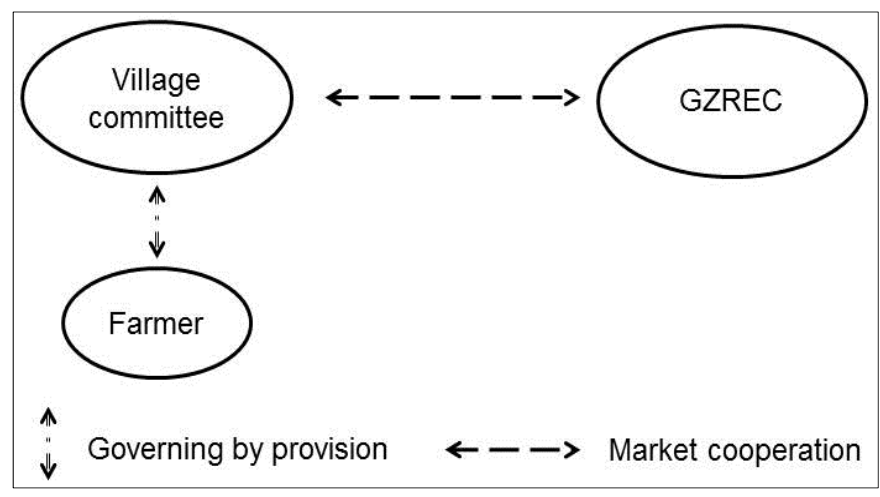

The village leader informed the farmers about the technology, market and policies, compiling a handbook. In order to involve farm households in jatropha plantation and cultivation, the village committee and secretary persuaded farmers to participate. Furthermore, the village committee also gave away its control over the use rights of collectively-owned forestland and distributed the land among the farmers to incentivise their participation and organise jatropha planting. Finally, the village committee convinced farmers that the company could be trusted. The farmers were highly motivated because the private company and village committee took many measures (see also Table 5 for the contribution of resources).

Table 5. Contribution of resources to the market driven arrangement.

\begin{tabular}{|c|c|c|c|}
\hline \multirow{2}{*}{ Actor } & \multicolumn{3}{|c|}{ Resources contributed to arrangement } \\
\hline & Category & Description & Time \\
\hline \multirow[t]{3}{*}{ Village leaders } & Staff & Coordination of labour & Plantation period and harvest period \\
\hline & Access & $\begin{array}{l}\text { Access to forestland; } \\
\text { Access to farmers: use of } \\
\text { argumentative power for persuasion; } \\
\text { Access to company }\end{array}$ & $\begin{array}{l}\text { Before plantation; } \\
\text { Plantation period and harvest period } \\
\text { Before and during plantation period, } \\
\text { harvest period }\end{array}$ \\
\hline & $\begin{array}{l}\text { Social } \\
\text { capital }\end{array}$ & $\begin{array}{l}\text { Trust of farmers in village } \\
\text { government }\end{array}$ & Plantation period and harvest period \\
\hline \multirow[t]{3}{*}{ Company } & Finance & $\begin{array}{l}\text { Production costs } \\
\text { (seedlings, fertiliser, labour cost); } \\
\text { Purchase of all jatropha seeds at } \\
3 \mathrm{RMB} / \mathrm{kg} \text { or a higher market price. }\end{array}$ & $\begin{array}{l}\text { Plantation period; } \\
\text { Harvest period }\end{array}$ \\
\hline & Access & $\begin{array}{l}\text { Access to market; } \\
\text { Access to media }\end{array}$ & $\begin{array}{l}\text { Harvest period; } \\
\text { Plantation period } \\
\end{array}$ \\
\hline & Staff & $\begin{array}{l}\text { Company staff provides technical } \\
\text { service to villagers }\end{array}$ & Plantation period and harvest period \\
\hline \multirow[t]{3}{*}{ Villagers } & Labour & & Plantation period and harvest period \\
\hline & Expertise & $\begin{array}{l}\text { Know-how of jatropha cultivation } \\
\text { and harvest }\end{array}$ & Plantation period and harvest period \\
\hline & $\begin{array}{l}\text { Land use } \\
\text { right* }\end{array}$ & & In the beginning of the plantation \\
\hline
\end{tabular}

* Provided by the village committee. 
To establish a joint vision and discourse, the company also invited television to broadcast this project to a wider public during the planting phase, which increased confidence and trust among the villagers (interview with village leader). Furthermore, the company organised an introductory meeting and seminar, inviting village leaders from other areas and explaining the economic value of jatropha, the technology of jatropha plantation and the cooperative arrangement between the private company and village committee, in order to attract further participation. GZREC planned to grow 3333 ha in Pingguo County, and started to grow jatropha on 133 ha in Burong village in 2007. The private company offered important resources and attracted more participation through media and a seminar.

This market driven arrangement was based on market opportunity and economic interest. The private company at that time envisaged a market chance and promising bioenergy industry support by government subsidies. The village leader wanted to spur rural development by increasing employment and household incomes. Villagers need continuous income streams and are interested in quickly improving their living conditions.

\subsubsection{Performance}

At the beginning of 2008, around four months after the initial planting of 133 ha, frost destroyed the young jatropha forest. The programme was not continued after the frost and the hills were left barren. The company disappeared without fulfilling the contract, and hence the farmers did not receive any wages. Despite a written contract between the village committee and company, it was difficult to follow-up on this as the company disappeared and the village committee was not capable to effectuate the contract before court.

One reason why GZREC withdrew after the frost was that it expected (in vain) to receive a subsidy from the MOF. According to the "Management instruction on financial subsidy supporting the crops bases which produce Renewable Energy and Biochemical products" published by MOF, jatropha plantations only receive a subsidy if they reach 20,000 ha plantation and have an area of at least 33.3 ha nursery fields. Even if a refinery was under construction, GZREC did not qualify for the subsidies. Therefore, the frost might have simply been the trigger to quit the project.

\subsubsection{Lessons}

In the case of Guangxi, extreme weather conditions - not unique in China-formed a reason for the private company to withdraw the plantation. The significant factor for the failure in Guangxi was the strict requirements for subsidies from the MOF, i.e., in terms of the size of plantation area and the requirement to have a refinery close to the plantation, which resulted in the private company's failure to receive subsidies.

In a market driven arrangement, even with contracts, the private company in Guangxi was also able to withdraw. This case reflects the state of the rule of (contract) law in transitional China, where the legal system is underdeveloped. There is insufficient coordination and supervision to legally sanction private (and state) actors not behaving according to written contracts. The lack of involvement of higher governmental levels and the non-fulfilment of company promises in contract farming reinforced the difficulties of jatropha plantation, not unlike in other Asian cases [12]. 
In conclusion, a private company chose to withdraw triggered by an extreme weather event and unclear conditions of financial support. The lack of insufficient coordination and supervision made legal sanctions impossible. Support for private companies through subsidies from the central government based on transparent conditions and disaster insurance services from insurance companies [42] could reduce the probability of their early drop out in a market arrangement.

\section{Conclusions}

Given that jatropha is generally known for surviving on marginal land and under harsh conditions, it was considered as a promising fuel stock by the Chinese government. Expectations that it would not compete with food crops on agricultural land and could make use of the country's large marginal land endowment have been high. However, despite the government's promotion of jatropha, it did not build up a robust market environment. The rather late formulation of standards for biodiesel (especially the B5) and the absence of mandatory targets for biodiesel illustrate the underdeveloped biodiesel policy and regulation during the first decade of the new millennium in China. Nonetheless, through programmes and plans, the government devised some investment environment. Therefore, China also reflects the case of other developing countries where policies are not always well developed but programmes are devised for establishing a new sector [43].

The analysis of the jatropha biofuel projects and plantation indicates that an ambitious plan turns out to be stagnating. This article has focused on examining the main institutional reasons behind the stagnation of jatropha plantation. Accordingly, two arrangements have been identified, namely a government driven and market driven arrangement. However, as our case studies show, the institutional arrangements within programmes of two failed projects have been rather weak. In order to circumvent the risks of failure discussed in this analysis, jatropha, like other perennial plantations, requires institutional arrangements that keep stakeholders of the biodiesel production chain involved over a long time period. However, the time perspectives do not match across governmental levels and towards non-governmental stakeholders in the two cases. In the government driven arrangement, the state-owned enterprise has also not been reliable in devising future perspectives in this arrangement, while sanctioning rules have not been effective in preventing this enterprise's withdrawal. Hence, the mutual resource dependency of the local government and farmers in this case does not reduce uncertainty, due to the high dependency on the less place-based actor. Moreover, whereas the national government employs a rather comprehensive discourse around the use of forests for biodiesel production and shows a long-term perspective, our analysis illustrates that short-term incentives and immediate benefits will be more relevant for local governments and farmers involved in a government driven arrangement. For the case of the market driven arrangement, ministry's subsidy requirements for jatropha plantations (refinery and area size) make such small-scale private initiatives like that of Guangxi nearly impossible. The aforementioned sanctioning rules are also less favourable to this arrangement. In conclusion, both the government driven and market driven arrangements in place have failed to establish sustainable commitments with different actors over a long time span.

An institution is any structure or mechanism of social order governing the behaviour of a set of individuals within a given community. Basically, institutions always matter, as without institutions no social order is possible. However, in these cases the specific design of the institutions did not give the desired result, hence the institutional design was inadequate for the goals to be obtained. These 
insights from the cases show the importance of adequate institutional design to secure the success and continuation of jatropha projects.

Several lessons can be drawn from our analysis. In order to create a sustained market environment, a better implementation of the rules of law and sanctioning rules to prevent withdrawal of actors is necessary for both government and market driven arrangements. Furthermore, jatropha plantations need strong and continuous financial support from government agencies and companies to provide shared long-term perspectives and reimburse smallholders according to their annual time horizons in both arrangements. Additionally, mandatory blending requirements provide crucial framework conditions for both arrangements, in terms of increasing planning certainty. In addition, potential measures to enhance shared long-term perspectives in market driven arrangements might relate to hazard insurance services that could strengthen the commitment of market parties. Furthermore, the independent monitoring of contract farming and legal services to farmers is significant to create reliable market relations. In government driven arrangements, the effectuation of sanctions towards higher-level administrations (or the CNPC in this case) seems to be an issue to address, particularly given other actors' dependency on their resources. A further obstacle is the difference in time perspectives across local and higher level government administrations.

Despite having selected two cases that are representative for different types of institutional arrangements, we cannot provide a full picture of China's biodiesel production from jatropha through a large survey. Furthermore, technical constraints to jatropha production are not dealt with within this article's focus on institutional arrangements and time perspectives, despite clearly playing an important role for the success of this biodiesel crop. However, this article brings a new understanding of how to increase the resilience to the consequences of technical uncertainties, and ultimately, how to support the long-term success of jatropha biofuel development. Based on the findings of this article, we believe sustained commitments with different actors over a long time are important constituents for the future study concerning the success of jatropha plantations.

\section{Acknowledgments}

This research was carried out within the research project SURE (SUstainable Natural REsource Use in Rural China [44]), which is funded by the Royal Netherlands Academy of Arts and Sciences (KNAW), grant 08-PSA-E-02, and the Chinese Ministry of Science and Technology (MoST), grant 2008DFA90630, as part of the Programme Strategic Scientific Alliances.

\section{Author Contributions}

The individual contributions and responsibilities of the authors were as follows: Jia Li took the lead in the preparation of the paper, was grant holder of research financing and conducted the field work. Bettina Bluemling contributed to the development of the survey instrument and the development of the paper. Arthur Mol and Thomas Herzfeld contributed to the research design and the development of the paper.

\section{Conflicts of Interest}

The authors declare no conflict of interest. 


\section{References and Notes}

1. Hill, J.; Nelson, E.; Tilman, D.; Polasky, S.; Tiffany, D. Environmental, economic, and energetic costs and benefits of biodiesel and ethanol biofuels. Proc. Natl. Acad. Sci. USA 2006, 103, 11206-11210.

2. Scharlemann, J.P.W.; Laurance, W.F. How green are biofuels? Science 2008, 319, 43-44.

3. Mol, A.P.J. Boundless biofuels? Between vulnerability and environmental sustainability. Sociol. Rural. 2007, 47, 297-315.

4. Mol, A.P.J. Environmental authorities and biofuel controversies. Environ. Polit. 2010, 19, 61-79.

5. Oosterveer, P.; Mol, A.P.J. Biofuels, trade and sustainability: A review of perspectives for developing countries. Biofuels Bioprod. Biorefin. 2010, 4, 66-76.

6. Van Eijck, J.; Romijn, H. Prospects for Jatropha biofuels in Tanzania: An analysis with strategic niche management. Energy Policy 2008, 36, 311-325.

7. Wu, W.; Huang, J.; Deng, X. Potential land for plantation of Jatropha curcas as feedstocks for biodiesel in China. Sci. China Earth Sci. 2010, 53, 120-127.

8. Maes, W.H.; Trabucco, A.; Achten, W.M.J.; Muys, B. Climatic growing conditions of Jatropha curcas L. Biomass Bioenergy 2009, 33, 1481-1485.

9. Boerstler, F. The Potential for the Production of Bioenergy for Lighting and Cooking Using Jatropha (Jatropha curcas L. Euphorbiaceae) by Small Scale Farmers on the Kenyan Coast; GRIN Publisher: Munich, Germany, 2010.

10. Francis, G.; Edinger, R.; Becker, K. A concept for simultaneous wasteland reclamation, fuel production, and socio-economic development in degraded areas in India: Need, potential and perspectives of Jatropha plantations. Nat. Resour. Forum 2005, 29, 12-24.

11. Wang, Z. Producing Jatropha Biodiesel in China: Policy, Performance and Challenges. In Jatropha, Challenges for a New Energy Crop; Carels, N., Bahadur, B., Sujatha, M., Eds.; Springer: New York, NY, USA, 2012; Volume 1, pp. 95-121.

12. Gilbert, N. Local benefits: The seeds of an economy. Nature 2011, 474, S18-S19.

13. Kant, P.; Wu, S. The extraordinary collapse of Jatropha as a global biofuel. Environ. Sci. Technol. 2011, 45, 7114-7115.

14. Hoogstra, M.A. Coping with the Long Term-An Empirical Analysis of Time Perspectives, Time Orientations, and Temporal Uncertainty in Forestry. Ph.D. Thesis, Wageningen University, Wageningen, The Netherlands, 2008.

15. State Forestry Administration. Forestry Biomass Development Capacity and Strategy Research Report; State Forestry Administration: Beijing, China, 2006.

16. Guizhou People's Government. Eleventh Five-Year Development Plan; Guizhou People's Government: Guiyang, China, 2006.

17. Sichuan People's Government. Eleventh Five-Year Development Plan; Sichuan People's Government: Chengdu, China, 2006.

18. Huaxi City News, When will the biodiesel produced by jatropha from east of panzhihua really support the airplane? Chengdu, China, 2011.

19. Science Times, Biofuel: Jatropha’s sink, Beijing, China, 2011. 
20. Hainan Daily, Raw material become main bottleneck in development: When will biodiesel industry be successful? Haikou, China, 2011.

21. Yang, C.; Fang, Z.; Li, B.; Long, Y. Review and prospects of Jatropha biodiesel industry in China. Renew. Sustain. Energy Rev. 2012, 16, 2178-2190.

22. Yang, J.; Dai, G.; Ma, L.; Jia, L.; Wu, J.; Wang, X. Forest-based bioenergy in China: Status, opportunities, and challenges. Renew. Sustain. Energy Rev. 2013, 18, 478-485.

23. Verschuren, P. Case study as a research strategy: Some ambiguities and opportunities. Int. J. Soc. Res. Methodol. 2003, 6, 121-139.

24. Yin, R.K. Case Study Research: Design and Methods, 3rd ed.; Sage: Thousand Oaks, CA, USA; London, UK; New Delhi, India, 1989.

25. Arts, B.; Leroy, P.; van Tatenhove, J. Political modernisation and policy arrangements: A framework for understanding environmental policy change. Public Organ. Rev. 2006, 6, 93-106.

26. Van Gossum, P.; Arts, B.; de Wulf, R.; Verheyen, K. An institutional evaluation of sustainable forest management in Flanders. Land Use Policy 2011, 28, 110-123.

27. Liefferink, D.; Arts, B.; Leroy, P. The Dynamics of Policy Arrangements: Turning Round the Tetrahedron. In Institutional Dynamics in Environmental Governance; Arts, B., Leroy, P., Eds.; Springer: Frankfurt, Germany, 2006; pp. 45-68.

28. Arts, B.; van Tatenhove, J. Policy and power: A conceptual framework between the "old" and "new" policy idioms. Policy Sci. 2004, 37, 339-356.

29. Olsson, P.; Folke, C. Adaptive comanagement for building resilience in social-ecological systems. Environ. Manag. 2004, 34, 75-90.

30. Hoogstra, M.A.; Schanz, H. Future orientation and planning in forestry: A comparison of forest managers' planning horizons in Germany and the Netherlands. Eur. J. For. Res. 2009, 128, 1-11.

31. Hoogstra, M.A.; Schanz, H. How (un)certain is the future in forestry? A comparative assessment of uncertainty in the forest and agricultural sector. For. Sci. 2008, 54, 316-327.

32. Hoogstra, M.A.; Schanz, H. The future orientation of foresters: An exploratory research among Dutch foresters into the prerequisite for strategic planning in forestry. For. Policy Econ. 2008, 10, 220-229.

33. Kurttila, M.; Hämäläinen, K.; Kajanus, M.; Pesonen, M. Non-Industrial private forest owners' attitudes towards the operational environment of forestry-A multinominal logit model analysis. For. Policy Econ. 2001, 2, 13-28.

34. Mary, F.; Dupraz, C.; Delannoy, E.; Liagre, F. Incorporating agroforestry practices in the management of walnut plantations in Dauphiné, France: An analysis of farmers' motivations. Agrofor. Syst. 1998, 43, 243-256.

35. Dorfman, J.H.; Heien, D. The effects of uncertainty and adjustment costs on investment in the almond industry. Rev. Econ. Stat. 1989, 71, 263-274.

36. Kern, K.; Alber, G. Governing climate change in cities: Modes of urban climate governance in multi-Level systems. In Proceedings of the OECD Conference, Paris, France, 28-29 September 2009; pp. 171-196.

37. Yanbian County People's Government. Report on the Problems in Jatropha Forest Base Constructions; Yanbian County People's Government: Yanbian County, China, 2010; pp. 1-5. 
38. Xinhua Web, China will foster its high-quality energy forest base to 200 Million Mu until 2020, Beijing, China, 2009.

39. State Council Information Office of the People's Republic of China. Press Conference of the State Council Information Office of The State Forestry Administration provides answers about work undertaken in regard to climate change, Beijing, China, 2008.

40. State Forestry Administration. Promote forest-based biofuel and biomass- the seventh knowledge learning from $\mathrm{Hu}$ Jintao speech, Beijing, China, 2011.

41. Wang, X.; Xu, X.; Li, X. Provincial governors' turnovers and economic growth. China Econ. $Q$. 2009, 4, 1301-1328.

42. Oh, K.B.; Ho, C.B.; Wu, D.D. Natural disaster and financial risk management. Int. J. Emerg. Manag. 2009, 6, 215-226.

43. Habib-Mintz, N. Biofuel investment in Tanzania: Omissions in implementation. Energy Policy 2010, 38, 3985-3997.

44. Sustainable Natural Resource Use in Rural China. Available online: http://sure.ernasia.org (accessed on 22 November 2013).

(C) 2014 by the authors; licensee MDPI, Basel, Switzerland. This article is an open access article distributed under the terms and conditions of the Creative Commons Attribution license (http://creativecommons.org/licenses/by/3.0/). 